Gut, 1977, 18, 644-646

\title{
Selective IgA deficiency and Crohn's disease: report of two cases
}

\author{
H. J. F. HODGSON AND D. P. JEWELL \\ From the Academic Department of Medicine, Royal Free Hospital, London
}

SUMmaRY Two patients are described with Crohn's disease and selective IgA deficiency. Serum IgA was undetectable in each case, and immunoperoxidase studies of the lamina propria showed a gross diminution of $\operatorname{lgA}$-bearing plasma cells. Peripheral blood lymphocytes, however, showed normal numbers of IgA-bearing lymphocytes. The typical clinical course and histology in these two patients suggest that IgA-mediated responses in the mucosa are not involved in the pathogenesis of Crohn's disease.

Many immunological phenomena have been described in patients with Crohn's disease, including both humoral and cell-mediated responses to gutassociated antigens. Most immunohistochemical studies of the gut mucosa show that, as in the normal mucosa, the majority of plasma cells are IgA bearing (Skinner and Whitehead, 1974; Baklien and Brandtzaeg, 1975). Serum IgA levels are normal or raised. It is therefore of interest to report two cases of typical Crohn's disease associated with selective IgA deficiency. One such case has been described in full previously (Söltoft et al., 1972).

\section{Methods}

These two cases of selective IgA deficiency were recognised during the course of an immunological study of Crohn's disease. Sixty-four patients were studied. They were attending the gastroenterology outpatient clinics of the Royal Free Hospital, St. Mark's Hospital, and St. Thomas's Hospital, but were otherwise unselected. Immunoglobulin levels were measured in all these 64 patients.

\section{IMMUNOGLOBULIN LEVELS}

IgG, IgA, and IgM were estimated by single radial immunodiffusion using Hyland immunoplates. Absent IgA levels were confirmed using dilute anti-IgA antisera (Hyland) in agar plates, by double-diffusion against anti-IgA antiserum, and by immunoelectrophoresis using anti-IgA. IgE levels were measured by a radioimmunosorbent test (Phadebas). Normal ranges for Ig levels were derived from Received for publication 10 December 1976 measurements on 50 control subjects. These included healthy subjects and patients with peptic ulcer, irritable colon syndrome, and low back pain.

QUANTITATION OF IG-BEARING PERIPHERAL LYMPHOCYTES

A percentage of peripheral blood lymphocytes bearing IgG, IgA, and IgM was determined according to the method of Hayward and Greaves (1975), using fluoresceinated monospecific antisera to human IgG, IgA, and IgM (Wellcome). The number of fluorescing cells was expressed as a percentage of the total lymphocyte count.

\section{IMMUNOHISTOCHEMISTRY}

The number of immunoglobulin-containing plasma cells in tissue sections was estimated using immunoperoxidase staining (Piris and Whitehead, 1974). The technique was also performed for secretory piece. In case 1 the study was performed on rectal biopsy material, and in case 2 on a section from bowel resected at laparotomy; the area studied was not grossly involved with disease.

\section{MILK ANTIBODIES}

The titre of circulatory antibodies to casein, $\alpha$ lactalbumin, and $\beta$ lactoglobulin was measured using tanned red-cell haemagglutination (Gunther et al., 1960). The purified milk proteins were a gift from Dr R. Lister of the National Institute for Research in Dairying.

CASE 1

A 47 year old Caucasian male presented to the Royal 
Free Hospital in 1975 with colicky abdominal pain, and two to three loose motions daily. He reported a $5 \mathrm{~kg}$ weight loss in the previous three months. In 1963 he presented in New Orleans, Louisiana, with diarrhoea and weight loss. Laparotomy revealed terminal ileitis, which was resected. Histology of the specimen confirmed Crohn's disease. Apart from a transient episode of pain and diarrhoea in 1968 he remained well on no specific therapy until 1975. At the time of study the only abnormality on examination was a non-tender mass in the right iliac fossa. Sigmoidoscopy was normal, but the histological appearances of a rectal biopsy specimen showed a mild increase in mononuclear cells within the lamina propria. Goblet cells were normal, but there was some invasion of the superficial epithelium by acute inflammatory cells. His ESR was $25 \mathrm{~mm} / \mathrm{h}$ Westergren, haemoglobin $14 \mathrm{~g} / \mathrm{dl}$, white blood count, and routine liver function tests normal. A barium meal and follow-through examination showed multiple strictures in the lower ileum typical of Crohn's disease, together with a malabsorption pattern. A barium enema showed some 'rose-thorn' ulceration in the region of the hepatic flexure and some shortening of the ascending colon. On treatment with systemic corticosteroids and sulphasalazine, his clinical condition improved, the abdominal mass resolved, and his ESR fell to $5 \mathrm{~mm} /$ h.

Review of the histological specimen obtained in 1963 showed a mixed inflammatory infiltrate involving the whole thickness of the wall, and noncaseating giant cell granulomata were present. The appearances were typical of Crohn's disease.

The immunological findings are summarised in the Table.

\section{CASE 2}

A 20 year old Caucasian female presented to St. Thomas's Hospital in 1966. She had a two-year history of weight loss and a diagnosis of anorexia nervosa had been considered. Radiological studies showed an ileocolitis, and subsequent laparotomy confirmed extensive inflammation in the terminal ileum, ascending colon, and non-adjacent areas of jejunum. A right hemicolectomy was performed, and the diagnosis of Crohn's disease was confirmed histologically. Since the operation, she has had relapses of disease which have responded to corticosteroid therapy. At the time of study she had active disease and was being treated with oral prednisolone.

Review of the histological specimens obtained in 1967 showed a transmural inflammation of the ileum and colon, with fissuring and non-caseating granulomata typical of Crohn's disease.

\section{Results of immunological tests}

These are summarised in the Table. Both patients had selective IgA deficiency with normal levels of IgG, IgM, and IgE. Repeat determinations of the serum immunoglobulin levels when the patients went into remission confirmed the selective IgA deficiency. Within the peripheral blood a normal percentage of lymphocytes bore IgA on their surface, and the number of IgG and IgM bearing lymphocytes were within the normal range for this laboratory. Tissue immunochemistry showed a gross reduction in IgA-containing cells. Precise quantitation of Ig-containing cells was not attempted. Patient 1 had an antibody titre of 1:250 to each of the three milk proteins but no milk antibodies were detected in the serum of patient 2.

\section{Discussion}

Selective IgA deficiency is the commonest immunoglobulin deficiency and is found from 1 in 500 to 1 in 700 of the general population (Hobbs, 1968; Bachmann, 1972). The occurrence of this deficiency in two out of 64 patients cannot be regarded necessarily as the frequency of IgA deficiency associated with Crohn's disease, as the study was not designed to elucidate this matter. Perret et al. (1971) reported no cases of IgA deficiency among 91 patients with Crohn's disease; on the other hand, among 42 patients studied in Copenhagen, one had selective

Table Immunological findings in two patients with selective IgA deficiency

\begin{tabular}{|c|c|c|c|c|c|c|c|c|c|c|c|c|}
\hline & \multicolumn{4}{|c|}{ Serum immunoglobulins } & \multirow{2}{*}{$\begin{array}{l}\text { Total } \\
\text { lympho- } \\
\text { cyte } \\
\text { count/mm }\end{array}$} & \multicolumn{3}{|c|}{$\begin{array}{l}\text { Ig-bearing lymphocytes } \\
\% \text { lymphocytes }\end{array}$} & \multicolumn{4}{|c|}{$\begin{array}{l}\text { Tissue immunohistochemistry } \\
\text { Ig-containing cells }\end{array}$} \\
\hline & $\begin{array}{l}I g G \\
(g / l)\end{array}$ & $\begin{array}{l}\operatorname{IgA} \\
(g / l)\end{array}$ & $\begin{array}{l}\operatorname{Ig} M \\
(g / l)\end{array}$ & $\begin{array}{l}I g E \\
(g / m l)\end{array}$ & & $I g G$ & $\operatorname{Ig} A$ & $\operatorname{Ig} M$ & $I g G$ & $\operatorname{Ig} A$ & $\operatorname{Ig} M$ & $\begin{array}{l}\text { Secretory } \\
\text { piece }\end{array}$ \\
\hline $\begin{array}{l}\text { Patient } 1 \\
\text { Patient } 2 \\
\text { Normal range }\end{array}$ & $\begin{array}{l}1 \cdot 03 \\
1 \cdot 25 \\
0 \cdot 62-1 \cdot 44\end{array}$ & $\begin{array}{l}0 \\
0 \\
0 \cdot 105-0 \cdot 55\end{array}$ & $\begin{array}{l}0 \cdot 1 \\
0 \cdot 113 \\
0 \cdot 04-0 \cdot 15\end{array}$ & $\begin{array}{l}24 \\
27 \\
5-440\end{array}$ & $\begin{array}{l}3024 \\
2268\end{array}$ & $\begin{array}{l}40 \\
44 \\
32-44\end{array}$ & $\begin{array}{l}2 \cdot 3 \\
6 \cdot 8 \\
2-7\end{array}$ & $\begin{array}{l}8 \cdot 3 \\
3 \cdot 4 \\
3-9\end{array}$ & $\begin{array}{l}\mathbf{N} \\
\mathbf{N}\end{array}$ & $\downarrow \downarrow$ & $\stackrel{\uparrow}{\mathbf{N}}$ & $\begin{array}{l}\mathbf{N} \\
\mathbf{N}\end{array}$ \\
\hline
\end{tabular}

$\mathbf{N}=$ Normal. $\downarrow \downarrow=$ grossly diminished. $\uparrow=$ increased.

Normal range for immunoglobulins determined on 50 control subjects. 
IgA deficiency (Weeke and Jarnum, 1971). This patient has been fully reported but few histological details were given (Söltoft et al., 1972). Likewise, no clinical details were given in the only other reported case of regional enteritis and selective IgA deficiency (Claman et al., 1970). The clinical and histological findings in the two patients reported here were typical of Crohn's disease.

Patients with selective IgA deficiency may remain completely well but they are prone to suffer from recurrent sinopulmonary infections, atopic disorders, coeliac disease, and autoimmune disorders (Ammann and Hong, 1971). None of these associated conditions was present in the two patients reported here. Their serum levels of IgG and IgM were normal, as is the case in the majority of patients with selective IgA deficiency; high titres of anti-milk antibodies, found in about $50 \%$ of patients with selective IgA deficiency, were found in one of our patients (Ammann and Hong, 1971).

Within the lamina propria of the gut mucosa, there was a gross diminution in IgA-containing cells, although a few were present. Within the peripheral blood, however, there was a normal number of $\operatorname{IgA}$ bearing lymphocytes. This pattern has been recognised before in patients with selective $\operatorname{IgA}$ deficiency (Cooper et al., 1972) and suggests that IgA deficiency may represent a failure of lymphocytes to mature into IgA-producing plasma cells.

Intestinal mucosa affected by Crohn's disease is densely populated with plasma cells producing all the major immunoglobulin classes (Baklien and Brandtzaeg, 1975). Humoral immune responses within the mucosa may therefore play a role in the pathogenesis of the disease. The finding of IgA deficiency in association with intestinal inflammation, which is clinically and histologically indistinguishable from Crohn's disease, suggests that IgA antibody is not an essential effector mechanism in the pathogenesis of this disease.

We are grateful to Dr J. Lennard-Jones and Dr B.
Creamer for allowing us to study their patients, and to Dr B. Creamer for permission to report case 2. This work was supported by a fellowship from the Stanley Thomas Johnson Memorial Fund to $\mathbf{H}$. J. F. Hodgson.

\section{References}

Ammann, A. J., and Hong, R. (1971). Selective IgA deficiency: presentation of 30 cases and a review of the literature. Medicine (Baltimore), 50, 223-236.

Bachmann, R. (1965). Studies on the serum $\gamma \mathrm{A}$-globulin level. III. Frequency A- $\gamma \mathrm{A}-g$ lobulinemia. Scandinavian Journal of Clinical Laboratory Investigation, 17, 316-320.

Baklien, K., and Brandtzaeg, P. (1975). Comparative mapping of the local distribution of immunoglobulin-containing cells in ulcerative colitis and Crohn's disease of the colon. Clinical and Experimental Immunology, 22, 197-209.

Claman, H. N., Merrill, D. A., Peakman, D., and Robinson, A. (1970). Isolated severe gamma A deficiency: immunoglobulin levels, clinical disorders and chromosome studies. Journal of Laboratory and Clinical Medicine, 75, 307-315.

Cooper, M D., Lawton, A. R., and Bockman, D. E. (1971). Agammaglobulinaemia with B lymphocytes. Specific defect of plasma cell differentiation. Lancet, 2, 791-795.

Gunther, M., Aschaffenburg, R., Matthews, R. H., Parish, W. E., and Coombs, R. R. A. (1960). The levels of antibodies to proteins of cow's milk in the serum of normal human infants. Immunology, 3, 296-306.

Hayward, A. R., and Greaves, M. F. (1975). Central failure of B-lymphocyte induction in pan-hypogammaglobulinemia. Clinical Immunology and Immunopathology, 3, 461470.

Hobbs, J. R. (1968). Immune imbalance in dysgammaglobulinaemia, type IV. Lancet, 1, 110-114.

Perrett, A. D., Higgins, G., Johnston, H. H., Massarella, G. R., Truelove, S. C., and Wright, R. (1971). The liver in Crohn's disease. Quarterly Journal of Medicine, 40, 187209.

Piris, J., and Whitehead, R. (1974). An immunoperoxidase technique for the identification of gastrin-producing cells. Journal of Clinical Pathology, 27, 798-799.

Skinner, J. M., and Whitehead, R. (1974). The plasma cells in inflammatory disease of the colon: a quantitative study. Journal of Clinical Pathology, 27, 643-646.

Söltoft, J., Petersen, L., and Kruse, P. (1972). Immunoglobulin deficiency and Regional Enteritis. Scandinavian Journal of Gastroenterology, 7, 233-236.

Weeke, B., and Jarnum, S. (1971). Serum concentration of 19 serum proteins in Crohn's disease and ulcerative colitis. Gut, 12, 297-302. 